\title{
THE 5-YEAR DYNAMICS OF CARDIAC STRUCTURE AND FUNCTION IN PATIENTS WITH CORONARY ARTERY DISEASE AFTER MYOCARDIAL REVASCULARIZATION
}

DOI: 10.36740/WLek202004119

\author{
Roksolana R. Guta, Olena M. Radchenko, Olga Ya. Korolyuk \\ DANYLO HALYTSKY LVIV NATIONAL MEDICAL UNIVERSITY, LVIV, UKRAINE
}

\begin{abstract}
The aim: To estimate the dynamics of echocardiographic parameters in patients with $C A D$ within 5 years after revascularization.

Material and methods: 50 persons (males/females 39/11; mean age $59.9 \pm 9.3$ years; STEMI $76 \%$, non-STEMI $24 \%$ ) were divided into two groups: $\mathrm{n}=38$ after $\mathrm{PCl}$ with stenting (PCIwS); $\mathrm{n}=12$ after CABG. Observation included regular echocardiography with LV myocardial mass (LVMM) and geometry estimation.

Results: Groups were comparable by age, co-morbidity, BP, heart rate and BMI. Significantly severe baseline LV hypertrophy (LVH) and left atrial enlargement (LAE) in group 2 explained by spread coronary atherosclerosis. Later progressive $L A E\left(4.37 \pm 0.22 \mathrm{~cm}, \mathrm{P}_{0.60}<0.05\right)$ in group 1 , and aortic/LV dilatation $\left(+0.4 /+1.0 \mathrm{~cm}\right.$, respectively, both $\left.\mathrm{P}_{0.60}<0.05\right)$ in group 2 developed. In two years LVMM index increased by $13.4 / 17.5 \%$ in groups $1 / 2$, respectively. Normal geometry and concentric remodeling completely disappeared in $3 / 1.5$ years after $P C I w S / C A B G$, respectively.

Conclusions: Within the $1^{\text {st }}$ year after revascularization, patients with CABG had more severe LVH. In 5 years after PCIwS the ratio between concentric/eccentric LVH was 2:1, whereas after $C A B G-1: 2$.
\end{abstract}

KEY WORDS: coronary artery disease, myocardial revascularization, coronary stenting, coronary artery bypass grafting, left ventricular geometry, left ventricular myocardial mass

Wiad Lek. 2020;73(4):728-732

\section{INTRODUCTION}

In patients with coronary artery disease (CAD) the period after myocardial revascularization is a complicated recovery process that maybe assessed by echocardiographic parameters and left ventricular (LV) indices. The process of LV remodeling may last for several years after an acute cardiovascular event [1]. During the recovery period, left ventricular hypertrophy (LVH) is not always a positive phenomenon, because changes in LV geometry may cause disturbances of contractility and increased myocardial stiffness [2]. Late remodeling involves LV hypertrophy and dilatation, resulting in both systolic and diastolic dysfunction. It is being considered as an independent risk factor for cardiovascular complications [3]. Some prospective studies demonstrated the correlations between LV mass and chamber size and the risk of cardiovascular complications.

Despite the presence or absence of traditional risk factors (e.g., dyslipidemia, overweight, diabetes mellitus, high blood pressure, endogenous intoxication, elder age), the incidence of cardiovascular complications is doubled in patients with $\mathrm{LVH}$, comparing to those without $[4,5,6$, 7]. $\mathrm{LV}$ wall thickening by $1 \mathrm{~mm}$ above the upper reference limit increases the risk of sudden cardiac death by 7 times, as well as the incidence of acute coronary syndrome and the need for myocardial revascularization $[5,8]$.

Usually patients stay under the supervision of a surgeon or an interventional cardiologist within several months after a revascularization procedure with further long-term surveillance by cardiologist in outpatient setting. To our knowledge, only few studies analyzed the influence of LV remodeling after myocardial revascularization on further course of CAD $[9,10]$ that prompted our study.

\section{THE AIM}

The aim of the study was to estimate the dynamics of echocardiographic parameters in patients with CAD during a 5 -year period after myocardial revascularization.

\section{MATERIALS AND METHODS}

The study had been carried out at the clinical bases of the Department of Internal Medicine No 2 Danylo Halytsky Lviv National Medical University. After obtaining a written consent in accordance with the principles of the Declaration of Helsinki, European Convention on Human Rights and Biomedicine, and relevant laws of Ukraine, fifty patients with $\mathrm{CAD}$ (39 men and 11 women; mean age $59.9 \pm 9.3$ years) were included into the study. Standard recommended examination revealed ST-Elevation Myocardial Infarction (STEMI) with Q wave in $48 \%$, STEMI without $\mathrm{Q}$ wave in $28 \%$, non-STEMI in $24 \%$. Depending on the type of revascularization, all partici- 
Table I. Echocardiographic parameters during a 5-year follow-up period after myocardial revascularization

\begin{tabular}{|c|c|c|c|c|c|c|c|c|c|c|c|}
\hline \multicolumn{2}{|c|}{$\begin{array}{l}\text { Time, } \\
\text { month }\end{array}$} & $\begin{array}{l}\text { RVD, } \\
\text { cm }\end{array}$ & $\begin{array}{l}\text { LAD, } \\
\text { cm }\end{array}$ & $\begin{array}{l}\text { IVST, } \\
\text { cm }\end{array}$ & $\begin{array}{l}\text { PWT, } \\
\text { cm }\end{array}$ & $\begin{array}{l}\text { LVID, } \\
\text { cm }\end{array}$ & $\begin{array}{c}\text { ARD, } \\
\text { cm }\end{array}$ & $\begin{array}{l}\text { LVEF, } \\
\%\end{array}$ & $\begin{array}{l}\text { LVMM, } \\
\mathrm{g}\end{array}$ & $\begin{array}{c}\text { iLVMM, } \\
\mathrm{g} / \mathrm{m}^{2}\end{array}$ & $\begin{array}{l}\text { RWT, } \\
\text { units }\end{array}$ \\
\hline \multirow{9}{*}{$\begin{array}{l}\bar{o} \\
\frac{0}{7} \\
\frac{0}{v}\end{array}$} & 0 & $\begin{array}{c}2,29 \pm \\
0,05\end{array}$ & $\begin{array}{c}3,72 \pm 0,09 \\
*, 6,10,14,21\end{array}$ & $\begin{array}{c}1,12 \pm \\
0,03^{*, 7,22}\end{array}$ & $\begin{array}{l}1,06 \pm \\
0,03^{1}\end{array}$ & $\begin{array}{c}4,71 \pm 0,08 \\
*, 3,8,12,15,19\end{array}$ & $\begin{array}{c}3,12 \pm \\
0,06\end{array}$ & $56 \pm 3$ & $\begin{array}{c}223 \pm 12 \\
*, 4,9,13,17,20\end{array}$ & $\begin{array}{c}107 \pm 6 \\
*, 2,5,18,21\end{array}$ & $\begin{array}{c}0,45 \pm \\
0,01\end{array}$ \\
\hline & 3 & $\begin{array}{c}2,27 \pm \\
0,04\end{array}$ & $3,83 \pm 0,12$ & $\begin{array}{l}1,12 \pm \\
0,03 *\end{array}$ & $\begin{array}{c}1,07 \pm \\
0,03\end{array}$ & $\begin{array}{c}4,87 \pm \\
0,13\end{array}$ & $\begin{array}{l}3,05 \pm \\
0,07^{*}\end{array}$ & $54 \pm 3$ & $236 \pm 17$ & $126 \pm 11$ & $\begin{array}{c}0,44 \pm \\
0,02 \\
\end{array}$ \\
\hline & 6 & $\begin{array}{c}2,30 \pm \\
0,06\end{array}$ & $3,95 \pm 0,09$ & $\begin{array}{c}1,17 \pm \\
0,05\end{array}$ & $\begin{array}{c}1,11 \pm \\
0,05\end{array}$ & $\begin{array}{c}4,93 \pm \\
0,12 \\
\end{array}$ & $\begin{array}{c}3,21 \pm \\
0,11 \\
\end{array}$ & $52 \pm 2$ & $256 \pm 18^{*}$ & $127 \pm 9^{5}$ & $\begin{array}{c}0,45 \pm \\
0,02 \\
\end{array}$ \\
\hline & 12 & $\begin{array}{c}2,31 \pm \\
0,06\end{array}$ & $4,03 \pm 0,1^{6}$ & $\begin{array}{l}1,28 \pm \\
0,05^{7}\end{array}$ & $\begin{array}{c}1,14 \pm \\
0,05\end{array}$ & $\begin{array}{l}5,07 \pm \\
0,13^{8} \\
\end{array}$ & $\begin{array}{c}3,24 \pm \\
0,1 \\
\end{array}$ & $53 \pm 2$ & $297 \pm 23^{9}$ & $122 \pm 9$ & $\begin{array}{c}0,45 \pm \\
0,02\end{array}$ \\
\hline & 18 & $\begin{array}{c}2,43 \pm \\
0,09\end{array}$ & $4,04 \pm 0,13$ & $\begin{array}{c}1,17 \pm \\
0,04\end{array}$ & $\begin{array}{c}1,12 \pm \\
0,04\end{array}$ & $\begin{array}{l}4,74 \pm \\
0,14^{*}\end{array}$ & $\begin{array}{c}3,24 \pm \\
0,06\end{array}$ & $50 \pm 2$ & $240 \pm 18^{*}$ & $120 \pm 11^{*}$ & $\begin{array}{c}0,48 \pm \\
0,02 \\
\end{array}$ \\
\hline & 24 & $\begin{array}{c}2,36 \pm \\
0,12 \\
\end{array}$ & $4,07 \pm 0,16^{10}$ & $\begin{array}{l}1,26 \pm \\
0,09^{11} \\
\end{array}$ & $\begin{array}{c}1,13 \pm \\
0,08 \\
\end{array}$ & $\begin{array}{c}5,2 \pm \\
0,29^{12} \\
\end{array}$ & $\begin{array}{l}3,2 \pm \\
0,16 \\
\end{array}$ & $54 \pm 3$ & $313 \pm 54^{13}$ & $122 \pm 20$ & $\begin{array}{c}0,44 \pm \\
0,02 \\
\end{array}$ \\
\hline & 36 & $\begin{array}{c}2,28 \pm \\
0,09\end{array}$ & $4,17 \pm 0,2^{14}$ & $\begin{array}{c}1,22 \pm \\
0,09\end{array}$ & $\begin{array}{c}1,14 \pm \\
0,06\end{array}$ & $\begin{array}{c}5,2 \pm \\
0,21^{15}\end{array}$ & $\begin{array}{c}3,13 \pm \\
0,16\end{array}$ & $55 \pm 5$ & $299 \pm 43^{17}$ & $133 \pm 19^{18}$ & $\begin{array}{c}0,44 \pm \\
0,01 \\
\end{array}$ \\
\hline & 48 & $\begin{array}{c}2,27 \pm \\
0,24\end{array}$ & $4,03 \pm 0,44$ & $\begin{array}{c}1,22 \pm \\
0,07\end{array}$ & $\begin{array}{c}1,18 \pm \\
0,06\end{array}$ & $\begin{array}{l}5,23 \pm \\
0,43^{19}\end{array}$ & $\begin{array}{c}3,03 \pm \\
0,2\end{array}$ & $54 \pm 6$ & $308 \pm 62^{20}$ & $141 \pm 16^{21}$ & $\begin{array}{c}0,46 \pm \\
0,02\end{array}$ \\
\hline & 60 & $\begin{array}{c}2,47 \pm \\
0,13 \\
\end{array}$ & $4,37 \pm 0,22^{21}$ & $\begin{array}{c}1,4 \pm \\
0,10^{22} \\
\end{array}$ & $\begin{array}{l}1,23 \pm \\
0,07^{1}\end{array}$ & $\begin{array}{l}5,57 \pm \\
0,18^{3} \\
\end{array}$ & $\begin{array}{c}3,33 \pm \\
0,24\end{array}$ & $47 \pm 4$ & $385 \pm 53^{4}$ & $176 \pm 20^{2}$ & $\begin{array}{c}0,44 \pm \\
0,01\end{array}$ \\
\hline \multirow{9}{*}{$\begin{array}{l}\text { N } \\
\text { 을 } \\
\text { 인 }\end{array}$} & 0 & $\begin{array}{c}2,34 \pm \\
0,11 \\
\end{array}$ & $4,09 \pm 0,18^{*}$ & $\begin{array}{l}1,23 \pm \\
0,06^{*}\end{array}$ & $\begin{array}{c}1,13 \pm \\
0,04\end{array}$ & $\begin{array}{c}5,11 \pm \\
0,24^{*, 23}\end{array}$ & $\begin{array}{l}3,17 \pm \\
0,10^{24} \\
\end{array}$ & $52 \pm 3$ & $286 \pm 26^{*}$ & $145 \pm 12^{*}$ & $\begin{array}{c}0,44 \pm \\
0,02 \\
\end{array}$ \\
\hline & 3 & $\begin{array}{c}2,43 \pm \\
0,17\end{array}$ & $3,90 \pm 0,24$ & $\begin{array}{l}1,26 \pm \\
0,07^{*}\end{array}$ & $\begin{array}{c}1,15 \pm \\
0,06\end{array}$ & $\begin{array}{c}4,83 \pm \\
0,23\end{array}$ & $\begin{array}{l}3,4 \pm \\
0,13^{*}\end{array}$ & $54 \pm 3$ & $271 \pm 34$ & $137 \pm 17$ & $\begin{array}{c}0,48 \pm \\
0,03\end{array}$ \\
\hline & 6 & $\begin{array}{c}2,44 \pm \\
0,10 \\
\end{array}$ & $4,25 \pm 0,21$ & $\begin{array}{c}1,26 \pm \\
0,06 \\
\end{array}$ & $\begin{array}{c}1,22 \pm \\
0,07 \\
\end{array}$ & $\begin{array}{c}5,21 \pm \\
0,14 \\
\end{array}$ & $\begin{array}{c}3,39 \pm \\
0,15 \\
\end{array}$ & $52 \pm 3$ & $311 \pm 17^{*}$ & $160 \pm 13$ & $\begin{array}{c}0,47 \pm \\
0,04\end{array}$ \\
\hline & 12 & $\begin{array}{c}2,37 \pm \\
0,15\end{array}$ & $4,37 \pm 0,17$ & $\begin{array}{c}1,18 \pm \\
0,11\end{array}$ & $\begin{array}{c}1,13 \pm \\
0,08\end{array}$ & $\begin{array}{c}5,03 \pm \\
0,32\end{array}$ & $\begin{array}{c}3,18 \pm \\
0,14\end{array}$ & $52 \pm 5$ & $266 \pm 24$ & $133 \pm 8$ & $\begin{array}{c}0,47 \pm \\
0,06\end{array}$ \\
\hline & 18 & $\begin{array}{c}2,38 \pm \\
0,17 \\
\end{array}$ & $4,28 \pm 0,17$ & $\begin{array}{l}1,3 \pm \\
0,17\end{array}$ & $\begin{array}{c}1,25 \pm \\
0,12 \\
\end{array}$ & $\begin{array}{l}5,45 \pm \\
0,27^{*} \\
\end{array}$ & $\begin{array}{c}3,48 \pm \\
0,21 \\
\end{array}$ & $54 \pm 5$ & $351 \pm 42^{*}$ & $176 \pm 20^{*}$ & $\begin{array}{c}0,47 \pm \\
0,06\end{array}$ \\
\hline & 24 & $\begin{array}{c}2,46 \pm \\
0,17\end{array}$ & $4,48 \pm 0,21$ & $\begin{array}{c}1,18 \pm \\
0,04\end{array}$ & $\begin{array}{c}1,08 \pm \\
0,10\end{array}$ & $\begin{array}{c}5,72 \pm \\
0,39\end{array}$ & $\begin{array}{c}3,34 \pm \\
0,20\end{array}$ & $47 \pm 4$ & $325 \pm 43$ & $171 \pm 25$ & $\begin{array}{c}0,39 \pm \\
0,05\end{array}$ \\
\hline & 36 & $\begin{array}{c}2,15 \pm \\
0,12\end{array}$ & $4,40 \pm 0,21$ & $\begin{array}{c}1,13 \pm \\
0,05\end{array}$ & $\begin{array}{c}1,03 \pm \\
0,11\end{array}$ & $\begin{array}{c}5,45 \pm \\
0,28\end{array}$ & $\begin{array}{c}3,05 \pm \\
0,03\end{array}$ & $45 \pm 4$ & $274 \pm 14$ & $141 \pm 3$ & $\begin{array}{c}0,38 \pm \\
0,06\end{array}$ \\
\hline & 48 & $\begin{array}{c}2,43 \pm \\
0,13\end{array}$ & $4,35 \pm 0,16$ & $\begin{array}{c}1,28 \pm \\
0,09\end{array}$ & $\begin{array}{c}1,07 \pm \\
0,1\end{array}$ & $\begin{array}{c}5,53 \pm \\
0,35\end{array}$ & $\begin{array}{c}3,42 \pm \\
0,17\end{array}$ & $48 \pm 5$ & $317 \pm 22$ & $155 \pm 8,5$ & $\begin{array}{c}0,40 \pm \\
0,06\end{array}$ \\
\hline & 60 & $\begin{array}{c}2,50 \pm \\
0,10\end{array}$ & $4,7 \pm 0,42$ & $\begin{array}{l}1,2 \pm \\
0,15\end{array}$ & $\begin{array}{c}1,07 \pm \\
0,07\end{array}$ & $\begin{array}{l}6,13 \pm \\
0,44^{23}\end{array}$ & $\begin{array}{l}3,57 \pm \\
0,19^{24}\end{array}$ & $45 \pm 3$ & $363 \pm 43$ & $164 \pm 38$ & $\begin{array}{c}0,35 \pm \\
0,04\end{array}$ \\
\hline
\end{tabular}

Notes: * intergroup differences $(P<0.05)$; $1-28$ - comparison of baseline and dynamic parameters within the group $(P<0.05)$.

pants had been divided into two groups, i.e., 38 persons after percutaneous coronary intervention with stenting (PCIwS) and 12 subjects after coronary artery bypass grafting (CABG), groups 1 and 2, respectively. All patients received standard therapy for CAD after revascularization. During a 5-year follow-up period, the participants underwent echocardiographic examination 3 and 6 months after procedure, next two years twice annually, and then annually. Transthoracic echocardiography was performed on the Kontron Sigma 44 apparatus (France) according to the Recommendations of the American Society of Echocardiography with measurement of the following parameters: right ventricular dimension (RVD), left atrial dimension (LAD), left ventricular internal end-diastolic diameter (LVID), posterior wall thickness (PWT), interventricular septum thickness (IVST), left ventricular ejection fraction (LVEF), and aortic root diameter (ARD). Left ventricular myocardial mass (LVMM) was calculated using Penn Convention formula: LVMM = 1.04 ([LVID + PWT + IVST $\left.]^{3}-[\mathrm{LVID}]^{3}\right)-13.6 \mathrm{~g}$, with subsequent indexation to body surface area (iLVMM) and calculation of relative LV wall thickness (RWT) for definition of LV geometry [11]. The values of iLVMM $>115 \mathrm{~g} / \mathrm{m}^{2}$ for males and $>95 \mathrm{~g} / \mathrm{m}^{2}$ for females and RWT $>0.42$ were considered as LVH criteria. Statistical analysis had been performed using the program «Statistica for Windows 6.0» (Statsoft, USA) with parametric methods, variables were presented as mean \pm standard deviation; Student's t-criterion was used for inter-group comparison; $\mathrm{P}$ values $<0.05$ were considered statistically significant. 


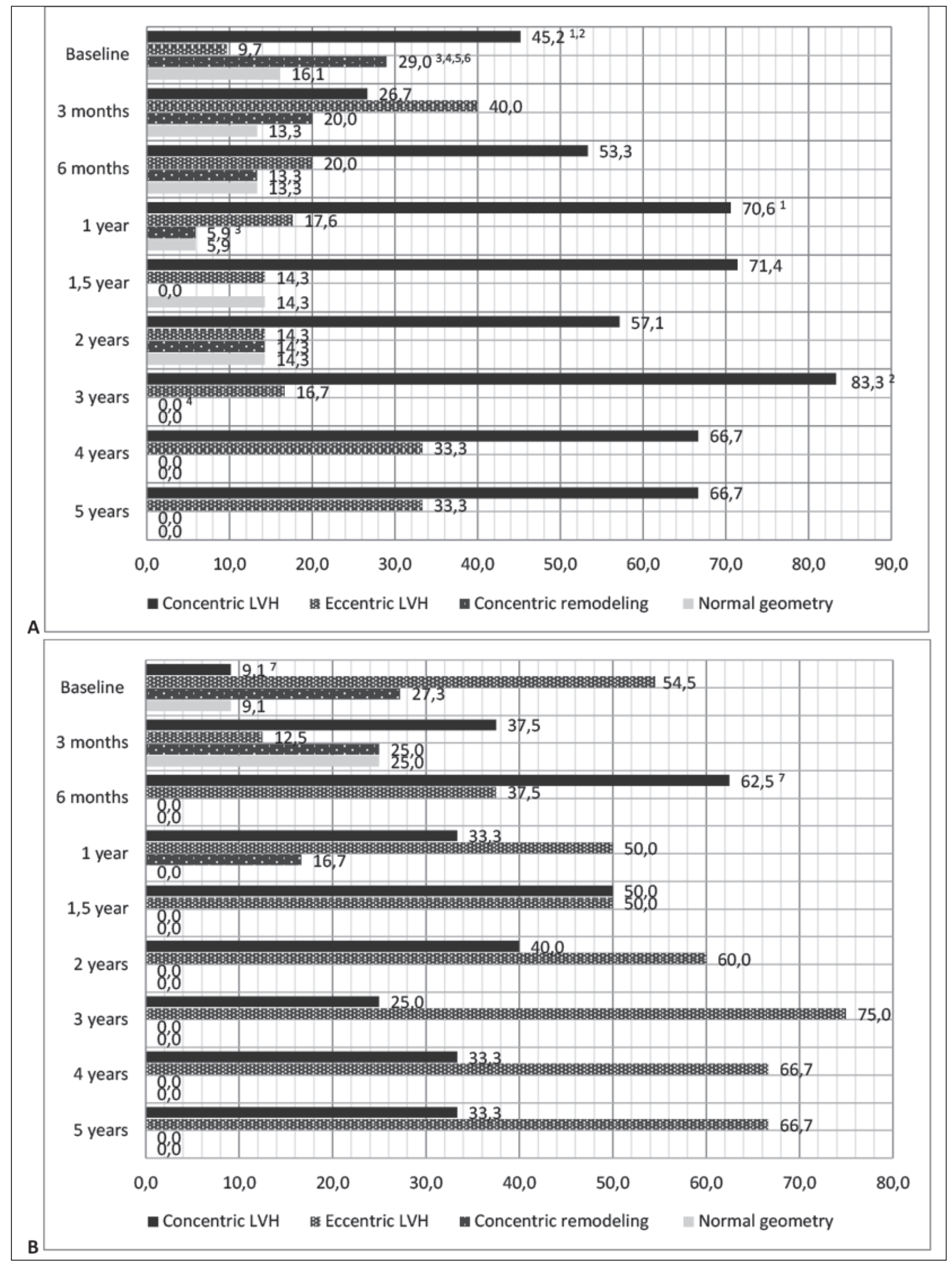

Figure 1. The prevalence of geometric LV patterns in patients after stenting (A) and CABG (B) Notes: 1-7 - comparison of baseline and dynamic parameters within the group $(P<0.05)$. 


\section{RESULTS AND DISCUSSION}

Although both groups did not significantly differ by the age, co-morbidity, blood pressure levels, heart rate and body mass index, some echocardiographic parameters and their dynamic changes were significant (table I).

Immediately after myocardial revascularization, group 2 patients had significantly more severe LV hypertrophy/ dilatation and left atrial enlargement according to their values of LVMM, iLVMM, IVST, LVID, and LAD than group 1 patients. Prominent cardiac remodeling in group 2 patients may be explained by more spread atherosclerosis as demonstrated by coronary angiography. Several studies showed that coronary atherosclerosis often results in LVH $[4,12]$. However, after 24 months and during the rest of follow-up period, no significant differences between groups were observed (Table I), regardless the type of revascularization.

Estimation of the 5-year dynamics of echocardiographic parameters revealed no significant changes in the RVD, RWT and LVEF, although the tendency to negative changes was still being traced in both groups. Left heart chambers (i.e., LAD, IVST, LVID, and LVMM) in group 1 patients were increasing gradually with a significant difference already in a year after procedure. Thus, the left atrial size in 12 months was above reference ranges $-4.03 \pm 0.10$ $\mathrm{cm}$, and continued to enlarge: in 2 years $-4.07 \pm 0.16 \mathrm{~cm}$ $\left(\mathrm{P}_{0-24}<0.05\right)$, in 3 years $-4.17 \pm 0.2 \mathrm{~cm}\left(\mathrm{P}_{0-36}<0.05\right)$, in 5 years $-4.37 \pm 0.22 \mathrm{~cm}\left(\mathrm{P}_{0-60}<0.05\right)$. Atrial remodeling is simultaneously a consequence and an evidence of diastolic dysfunction; it predisposes to lung congestion and arrhythmias, mainly atrial fibrillation.

Similar changes in the LV structure and geometry had been observed. LVID values increased significantly, from $4.71 \pm 0.08 \mathrm{~cm}$ to $5.07 \pm 0.13 \mathrm{~cm}$ in 12 months $\left(\mathrm{P}_{0-12}<0.05\right)$, $5.2 \pm 0.29 \mathrm{~cm}$ in 2 years $\left(\mathrm{P}_{0-24}<0.05\right)$, and $5.57 \pm 0.18 \mathrm{~cm}$ in 5 years $\left(\mathrm{P}_{0-60}<0.05\right)$. Patients after PCIwS initially had slightly increased values of IVST $(1.12 \pm 0.03 \mathrm{~cm})$ and PWT $(1.06 \pm 0.03 \mathrm{~cm})$. In one year after procedure the value of IVST significantly increased $\left(1.28 \pm 0.05 \mathrm{~cm}, \mathrm{P}_{0}\right.$ $\left.{ }_{12}<0.05\right)$, and in 5 years its value had become $25 \%$ higher than baseline $\left(1.40 \pm 0.05 \mathrm{~cm}, \mathrm{P}_{0-60}<0.05\right)$. The mean value of PWT also gradually increased, however, more slowly than IVST, and the difference became significant only in 5 years after PCIwS $\left(1.23 \pm 0.07 \mathrm{~cm}, \mathrm{P}_{0-60}<0.05\right)$. Besides, a significant increase in LVMM and its index had been found with moderate hypertrophy in one year $\left(297 \pm 23 \mathrm{~g}, \mathrm{P}_{0-12}\right.$ $<0.05)$ and severe hypertrophy in 3 years after procedure $\left(313 \pm 54 \mathrm{~g}, \mathrm{P}_{0-36}<0.05\right)$.

In contrast to group 1, echocardiographic parameters after CABG significantly increased only in 5 years, particularly LVID (from $5.11 \pm 0.24$ to $6.13 \pm 0.44 \mathrm{~cm}, \mathrm{P}_{0-60}<0.05$ ) and ARD (from $3.17 \pm 0.10$ to $3.57 \pm 0.19 \mathrm{~cm}, \mathrm{P}_{0-60}<0.05$ ). Besides, in 3 years after CABG a tendency toward moderate reduction of LVEF was observed (from $52 \pm 3 \%$ to $45 \pm$ $\left.4 \%, \mathrm{P}_{0-60}<0.1\right)$.

Our results suggest the constant progression of LVH and changes in the type of LV remodeling after both types of revascularization. According to the literature, patients with CAD usually have enlargement of LV sizes prior to surgery and at all stages of observation after CABG with increase in iLVMM by $8 \%$ till the end of the second year [13]. In our study during the same period of time, the LVMM index increased by $13.4 \%$ and $17.5 \%$ in groups 1 and 2 , respectively.

The prevalence of different geometric patterns of LV remodeling also had been estimated during 5 years of observation (Fig. 1). It is known that abnormal LV geometry is associated with worse prognosis, e.g., increased risks of systolic and/or diastolic LV dysfunction, cardiovascular events, and death [14]. The highest risk and worst prognosis had patients with a concentric LVH [15].

All four LV geometric patterns were encountered in both groups prior to revascularization. Both normal geometry and concentric remodeling were absent in all patients in 3 years after PCIwS, whereas in those after CABG it was observed already in 1.5 years. During the last two years of the observation, no changes in the prevalence of LV geometric patterns had been observed in both groups (Fig. 1).

Among group 1 patients, concentric LVH occurred 2.8 times more often than normal LV geometry and 4.7 times more often than eccentric LVH $(45.2 \%, 16.1 \%$, and 9.7\%, respectively); in 5 years its prevalence increased by $21.5 \%$ (from $45.2 \%$ to $66.7 \%$ ). Besides, 12 months after procedure, the prevalence of concentric remodeling reduced by 4.9 times (from $29.0 \%$ to $5.9 \%, \mathrm{p}<0.05$ ), and in 3 years this type of geometry was not detected at all. Thus, in 5 years after PCIwS $2 / 3$ patients had a concentric $\mathrm{LVH}$, and $1 / 3$ an eccentric $\mathrm{LVH}$ associated with $\mathrm{LV}$ dilatation.

The prevalence of geometric LV patterns in group 2 differed from that in group 1 , although at the beginning it looked the same: there were significantly more patients with eccentric LVH (54.5\%) that was 6 times higher than the prevalence of normal geometry and concentric LVH. The percentage of concentric LVH steadily increased, reaching statistical significance in 6 months, i.e., 6.9 times (Fig. 1). Subsequently, the percentage of eccentric LVH began to increase, suggesting the emergence of secondary remodeling, namely, LV dilatation. These findings somewhat contradicted the reports of other authors, which indicated that $24 \%$ of patients after revascularization had concentric remodeling [16]. We, in turn, noted that during the third year of observation all patients had LVH.

\section{CONCLUSIONS}

Immediately after CABG, patients with CAD had more severe LVH than patients after PCIwS, but starting from the second year of the observation these differences became not significant. In 5 years $2 / 3$ of patients after PCIwS had the concentric $\mathrm{LVH}$ and $1 / 3$ eccentric $\mathrm{LVH}$, whereas those after CABG had opposite percentage, i.e., $2 / 3$ eccentric LVH and $1 / 3$ concentric LVH.

Perspective is further study of cardiac structure and function after revascularization, depending on the level of biomarkers. 


\section{REFERENCES}

1. Dolzhenko M.M., Konoplyanik L.I., Potashev S.V., et al. Vplyv hipertenzyvnoho remodelyuvannya livoho shlunochka na miokardial'nu funktsiyu u khvorykh z postinfarktnoyu ishemichnoyu kardiomiopatiyeyu ta arterial'noyu hipertenziyeyu v konstelyatsiyi z nealkohol'noyu zhyrovoyu khvoroboyu pechinky [Influence of left ventricular hypertensive remodeling on myocardial function in patients with postinfarction ischemic cardiomyopathy and arterial hypertension in constellation with nonalcoholic fatty liver disease]. Collection of scientific works of NMAPE employees. P. L. Shupika. 2014; 23 (2): 323331. (in Ukrainian)

2. Sarafniuk 0.P., Denesyuk V.I., Shushkovskaya Yu. Vyznachennya stupeniv hipertrofiyi livoho shlunochka u khvorykh zi stabil'noyu stenokardiyeyu za dopomohoyu udoskonalenykh kryteriyiv diagnostyky [Determination of degrees of left ventricular hypertrophy in patients with stable angina with advanced diagnostic criteria]. Herald Morphology. 2015; 21 (1): 182-184. (in Ukrainian)

3. Fox K., Garcia M.A., Ardissino D. et al. Guidelines on the management of stable angina pectoris - The Task Force on the management of stable angina pectoris of the European Society of Cardiology. European Heart Journal. 2016; 27: 1341-1381. doi.org/10.1093/eurheartj/ehl001

4. Dolzhenko M.M., Perepelchenko N.A., Bazilevich A.A. Ishemichna khvoroba sertsya na tli tsukrovoho diabetu 2 typu: svoyeridnist' perebihu ta obhruntuvannya terapiyi [Ischemic diseases and hearts against the background of type 2 diabetes: the peculiarity of the course and the justification of therapy]. The electronic scientific journal of cardiology WebCardio.0rg. 2010. http://www.webcardio.org/SiteMap.aspx. (in Ukrainian)

5. Dahlof B., Devereux R., Kjeldsen S., et al. Cardiovascular morbidity and mortality in losartan interventional for endpoint reduction in hypertension study (LIFE): a randomized trial against atenolol. Lancet. 2002; 359: 995-1003. doi.org/10.1016/S1062-1458(02)00776-6

6. Kondratyuk M.0., Radchenko 0.M. Structural and functional heart parameters in patients with chronic heart failure depending on different blood middle mass molecules levels. Pharmacotherapy in Cardiology. 2013; 9(1): 40-43.

7. Filipyuk A.L. Strukturno-funktsional'ni sertsevi parametry u khvorykh z khronichnoyu ishemichnoyu khvoroboyu sertsya u poyednanni z nadmirnoyu vahoyu ta ozhyrinnyam: prohnozuvannya vyzhyvannya [Structural-Functional Cardiac Parameters in Patients with Chronic Ischemic Heart Disease Combined with Overweight and Obesity: Predictors of Survival]. JMBS. 2016; 1(1): 99-102. doi.org/10.26693/ jmbs01.01.099 (in Ukrainian)

8. Radchenko G.D., Sirenko Y.M. Hipertrofiya livoho shlunochka: vyznachennya, metody otsinky, mozhlyvosti rehresuvannya [Left ventricular hypertrophy: definition, evaluation methods, regression possibilities]. Arterial hypertension. 2010; 4 (12): 23-27. (in Ukrainian)

9. Agmatova Z.M., Kallayev A.N. Osobennosti progressirovaniya remodelirovaniya miokarda u bol'nykh s razlichnymi formami nestabil'noy stenokardii [Features of the progression of myocardial remodeling in patients with various forms of unstable angina pectoris]. Cardiology. 2014; 54 (7): 9-16. (in Russian)

10. Shah A.M., Shah S.J., Anand I.S., et al. Cardiac structure and function in heart failure with preserved ejection fraction: baseline findings from the echocardiographic study of the Treatment of Preserved Cardiac Function Heart Failure with an Aldosterone Antagonist trial. Circ. Heart. Fail. 2014; 7(1): $104-115$.
11. Genau A., Devereux R.B., Roman M., et al. Patterns of left ventricular hypertrophy and geometric remodeling in essential hypertension. J. Am. Coll. Cardiol. 1992; 19: 15501558. doi.org/10.1016/07351097(92)90617-v

12. Dotsenko N.A., Dotsenko Ya.N., Gerasimenko L.V., et al. Gipertrofiya levogo zheludochka i ateroskleroz [Left ventricular hypertrophy and atherosclerosis]. Arterial hypertension. 2011; 1 (15):21-29. (in Russian)

13. Nakonechny S.Yu. Yzmenenyya strukturno-heometrycheskykh y funktsyonal'nykh parametrov levoho zheludochka u bol'nykh YBS s Q-ynfarktom myokarda v anamneze do y posle AKSH [Changes in structural geometrical and functional parameters of the left ventricle in patients with coronary artery disease with a Q-myocardial infarction in history before and after CABG]. Chronicles of scientific works of the Association of Cardiovascular Surgeons of Ukraine. 2009; 17: 324-327. (in Russian)

14. Lieb W., Gona P., Larson M.G., et al. The Natural History of Left Ventricular Geometry in the Community. JACC: Cardiovascular Imaging. 2014; 7(9): 870-878. doi: 10.1016/j.jcmg.2014.05.008

15. Verma A., Meris A., Skali H., et al. Prognostic Implications of Left Ventricular Mass and Geometry Following Myocardial Infarction. JACC: Cardiovascular Imaging. 2008; 1 (5): 582-591. doi: 10.1016/j. jcmg.2008.05.012

16. Xu L., Huang X., Ma J., et al. Value of three-dimensional strain parameters for predicting left ventricular remodeling after ST-elevation myocardial infarction. Int. J. Cardiovasc. Imaging. 2017; 33(5): 663-673. doi: $10.3233 /$ XST-17316

The work is performed within the framework of the research work of the Department of Internal Medicine № 2 «Metabolic predictors of the course of diseases of the internal organs against the background of obesity and their predictive value». State registration number: $0107 \mathrm{U} 001050$.

\section{ORCID and contributionship:}

Roksolana R. Guta - 0000-0002-7078-8556 B,C,D

Olena M. Radchenko - 0000-0003-1108-963X ${ }^{A, F}$

Olga Ya. Korolyuk - 0000-0003-4236-2061 ${ }^{\mathrm{E}}$

\section{Conflicts of interest:}

Authors declare no conflict of interest.

\section{CORRESPONDING AUTHOR}

Roksolana R. Guta

69, Pekarska Street, Lviv, 79010, Ukraine

tel: +380996450049

e-mail:rshtoyko@gmail.com

Received: 10.07.2019

Accepted: 05.02.2020

A - Work concept and design, B - Data collection and analysis, C - Responsibility for statistical analysis,

D-Writing the article, $\mathbf{E}$-Critical review, $\mathbf{F}$ - Final approval of the article 